\title{
Applying The Extended Technology Acceptance Model To The Use Of Clickers In Student Learning: Some Evidence From Macroeconomics Classes
}

Xiaoyu Wu, Ramapo College of New Jersey, USA

Yuan Gao, Ramapo College of New Jersey, USA

\begin{abstract}
This paper applies the extended technology acceptance model (exTAM) in information systems research to the use of clickers in student learning. The technology acceptance model (TAM) posits that perceived ease of use and perceived usefulness of technology influence users' attitudes toward using and intention to use technology. Research subsequent to TAM has added perceived enjoyment as a factor in predicting attitude and behavioural intentions. This study tests the validity of this extended TAM model while applied to clickers via data collected from three macroeconomics classes. Path analytic results show that most of the hypotheses are supported in the expected directions, providing evidence that exTAM is applicable to examining factors influencing learner attitude and behaviour in relation to the use of interactive learning technologies, such as clickers in the classroom.
\end{abstract}

Keywords: technology acceptance model (TAM); educational technology; perceived enjoyment; student response system (SRS); clickers

\section{INTRODUCTION}

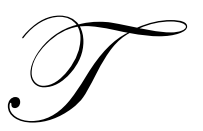

echnology-supported learning is a constant subject in educational research. The interaction between technology and participants impacts student learning processes as well as learning outcomes (Wan, Fang, \& Neufeld, 2007). Many studies have focused on such measurable learning outcomes as grades and performance while ignoring students' psychological learning processes (Bekele \& Menchaca, 2008), which may include learners' cognitive structures, interests, motivation, and information processing activities (Alavi $\&$ Leidner, 2001). Nonetheless, recent literature has shown encouraging progress in research exploring the affective dimension of technology-supported learning (Benbunan-Fich \& Hiltz, 2003; Stafford, 2005; Wan et al., 2007).

Researchers have advocated applying existing theories in closely-related reference disciplines to educational technology in theory building (Hrastinski \& Keller, 2007). This paper reviews literature on the technology acceptance model (TAM) and its extension in information systems research and reports finding from a field study of applying the extended TAM (exTAM) to the use of clickers, a student response system, in student learning.

\section{A STUDENT RESPONSE SYSTEM: CLICKERS}

While effectively engaging students in the learning process is a constant endeavour of college instructors, the diversity in student population in today's college classrooms makes the task more challenging. Modern technology has been increasingly used to enhance teaching and learning in such an effort. One such technology that increases student involvement and has been adopted by many instructors in recent years is the student response system (SRS). Each student uses a registered handheld portable device (clicker) with unique identification to answer 
questions posted by their instructors (multiple-choice, true-false, etc.). When a student "clicks" his/her choice of answer, the clicker transmits a radio signal to a receiver and thus individual responses are received and recorded. The instructor then is able to display the aggregate results in multimedia right away.

Recent literature has empirically examined the benefits of using SRS based on anecdotal observations, survey results as well as academic outcomes. Cain and Robinson (2008) provides a brief literature review. Studies have reported that using clickers fosters discussion and better interaction between instructors and students, increases student engagement and class participation, enhances student interest in lecture content and improves student performance on exams (see Cain \& Robinson, 2008). Some advantages of using clickers are summarized in Wood (2004). For example, the instructors are able to immediately assess student understanding and identify where students fumble around as well as access information on student attendance and performance later for purposes of grading and course management. On the student side, the anonymity provided by using clickers (individual responses will not show publicly) makes students less nervous--"no one has to worry about the possible humiliation of giving a 'dumb' answer" (Wood, 2004). Students who don't get a question right do not feel as bad seeing that the wrong answer is picked up by their classmates as well. It is also found that clickers benefit students who are frequently disadvantaged in the classroom, especially those with a low need for cognition or facing cultural barriers (Sprague \& Dahl, 2010). In the same line, Stowell and Nelson (2007) conclude that clickers may be a significant vehicle of participation for students who tend to be less talkative in class.

\section{THE TECHNOLOGY ACCEPTANCE MODEL (TAM)}

Based on the theory of reasoned actions (TRA) (Ajzen \& Fishbein, 1980), TAM addresses factors influencing a user's attitude toward using (ATT) and intention to use technology (Davis, Bagozzi, \& Warshaw, 1989). TAM has been widely adopted in studies exploring technology acceptance due to its parsimonious nature and highly reliable constructs. Examples include studies testing user acceptance of word processors (Davis et al., 1989), spreadsheet applications (Mathieson, 1991), email (Szajna, 1996), and websites (Gefen, Karahanna, \& Straub, 2003).

TAM considers perceived usefulness (PU) and perceived ease of use (PEOU) as two major factors influencing a user's attitude toward using technology. The former refers to the perceived effectiveness of improving the user's performance, while the latter refers to how effortless a user perceives using the technology to be. Prior research has found that PEOU mostly influences attitude and intention indirectly through PU (Davis, Bagozzi, \& Warshaw, 1992). Perceived usefulness and user attitude in turn influence intention to use, which predicts actual usage of technology. Treating the SRS as an educational technology used in the classroom, this paper proposes that the same relationships from TAM hold in relation to using the clickers in student learning.

H1: $\quad$ PEOU is positively associated with PU.

H2: $\quad$ PU is positively associated with ATT.

H3: PU is positively associated with Intention.

H4: $\quad$ ATT is positively associated with Intention.

\section{PERCEIVED ENJOYMENT}

Subsequent to TAM, other variables have been added to the model to form an extended TAM in the literature. Such variables include computer playfulness (Moon \& Kim, 2001), product involvement, and perceived enjoyment (PE) (Koufaris, 2002). The concept of perceived enjoyment is based on the flow theory, and is defined to be the extent to which an activity is perceived enjoyable in its own right aside from a user's perception of its usefulness or ability to achieve certain performance goals (Davis et al., 1992; Koufaris, 2002). According to the extended uses and gratifications theory, PE can also be seen as value inherent in an activity that fulfills the audience's needs for escapism, diversion, aesthetic enjoyment, or emotional release (McQuail, 1983). Batra and Ray 
(1986) find that PE as an intrinsic motivation enhances perceived usefulness in consumer research. This paper argues that the more enjoyable the experience, the higher value and more perceived usefulness derived from that interaction.

H5: PE is positively associated with PU.

A technology perceived easy to use will be considered more enjoyable to use than one that is cumbersome. A number of studies in the current literature have reported a significant effect of PEOU on PE while extending TAM to include PE in predicting user acceptance of technology (Moon \& Kim, 2001; Bruner \& Kumar, 2005). This study proposes a similar relationship in the context of a learning technology.

H6: PEOU is positively associated with PE.

Likable or pleasant activities impact attitude positively (Mitchell \& Olson, 1981; Ducoffe, 1996), while an irritating interaction has a negative effect on attitude (Gao, Koufaris, \& Ducoffe, 2004). Moon and Kim (2001) view $\mathrm{PE}$ as an intrinsic source of motivation for no reason other than the process itself and find that PE is positively related to attitude toward using technology. Other studies also find PE to be a strong predictor of attitude toward using the Internet (Novak, Hoffman, \& Yung, 2000), handheld Internet devices (Bruner \& Kumar, 2005), instant messaging (Lu, Zhou, \& Wang, 2008), and virtual reality (Shen \& Eder, 2009). This study expects the same relationship to hold for educational technology.

H7: PE is positively associated with ATT.

\section{RESEARCH FRAMEWORK}

With PE and related propositions integrated, Figure 1 summarizes the research framework of this study in an exTAM model in which perceived ease of use, perceived usefulness, and perceived enjoyment of using a learning technology positively influence learners' attitude and intentions.

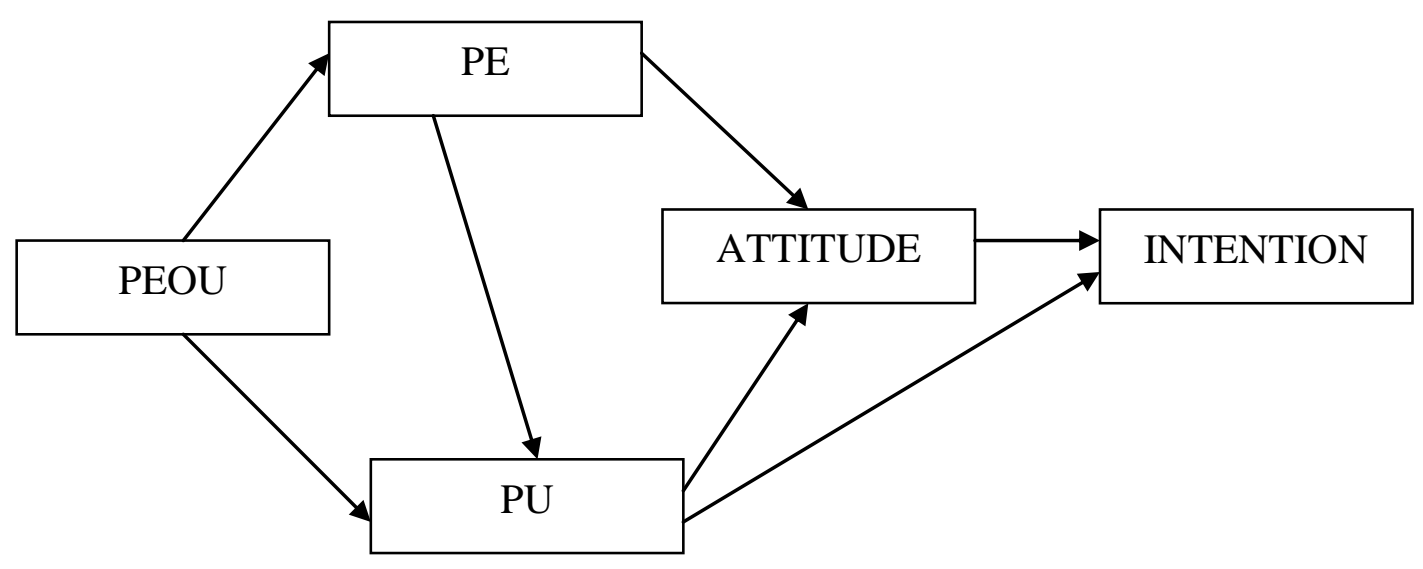

Figure 1: Research Framework

\section{METHODOLOGY}

The validity of the proposed relationships in the research model presented above was investigated through a field study. We incorporated use of iClickers (a version of the clickers named by Interactive Learning Technologies) in three sections of introductory macroeconomic classes in spring, 2009. The sections are of an 
average size of 35 students. At the end of each lecture (except sessions devoted for exams and exam reviews), students use the clickers to take a short quiz containing 5-10 questions on important concepts just covered in the lecture. The quiz questions are projected onto a screen and the students were asked to answer each question in a specified amount of time using the clickers. The aggregate result for each quiz question was shown and the solution was revealed immediately after voting was closed. Thus the students learned right away whether they had answered the question correctly as well as the entire class' overall performance on the question. Explanation and discussion followed to clarify any confusion and strengthen understanding. Students earned one point for each question they answered correctly and the performance on all quizzes accounted for $15 \%$ of the final course grade. At the end of the semester, a survey on student experiences with clickers was administered, during which the students were instructed to provide feedback on their experiences with clickers. The survey was developed in a way that the model constructs in TAM and exTAM were adapted to the context of using clickers. Scale items on the survey include those measuring PEOU, PU, PE, attitude and intention. The questionnaire contains no identifying information about the individual participants. A total of 101 questionnaires were collected.

Some basic demographic information is collected, indicating approximately $60 \%$ female and $40 \%$ male in the sample population, with an average age just under 20, reflecting the typical student group of introductory classes. The mean values (on a 7-point scale) for each construct in the model are 4.733 for PE, 5.856 for PEOU, 4.588 for PU, 4.935 for attitude, and 4.144 for Intention. Items on the survey are listed in Appendix A.

\section{MODEL TESTING}

All variables exhibit a high level of reliability with the Cronbach's alpha values (Table 1) exceeding the recommended 0.7 (Nunnally, 1978).

Table 1: Scale Reliability

\begin{tabular}{|l|l|}
\hline Scale & Cronbach's Alpha \\
\hline PE & .881 \\
\hline PEOU & .807 \\
\hline PU & .899 \\
\hline ATT & .850 \\
\hline Intention & .786 \\
\hline
\end{tabular}

The structural model is investigated using AMOS 17.0. Path analysis is performed on the model using standardized maximum likelihood estimation. The path analytic method offers the advantage of testing the overall model fit with multiple endogenous variables as in our model as well as individual a priori hypotheses.

The likelihood ratio chi-square test assesses the overall model fit. Chi-square is not significant in this case (Chi-square $=1.401, \mathrm{p}=0.705)$, indicating that the model cannot be rejected. Chi-square per degree of freedom (CMIN/DF), the relative Chi-square, is 0.467 , satisfying the recommend $<2$ criterion for a good fit. Other indices of model fit including goodness of fit index (GFI), normed fit index (NFI), and relative fit index (RFI) all exceed the recommended threshold level of 0.9 (GFI=0.994, NFI=0.996, RFI=0.980). The root mean square error of approximation (RMSEA) is .000, below the recommend 0.06 level (Hu \& Bentler, 1999). Thus the overall model has a good fit.

\section{RESULTS}

Correlations among the variables are illustrated in Figure 2. This model explains $76.6 \%$ of the variance in attitude and $69.2 \%$ of the variance in intention. 


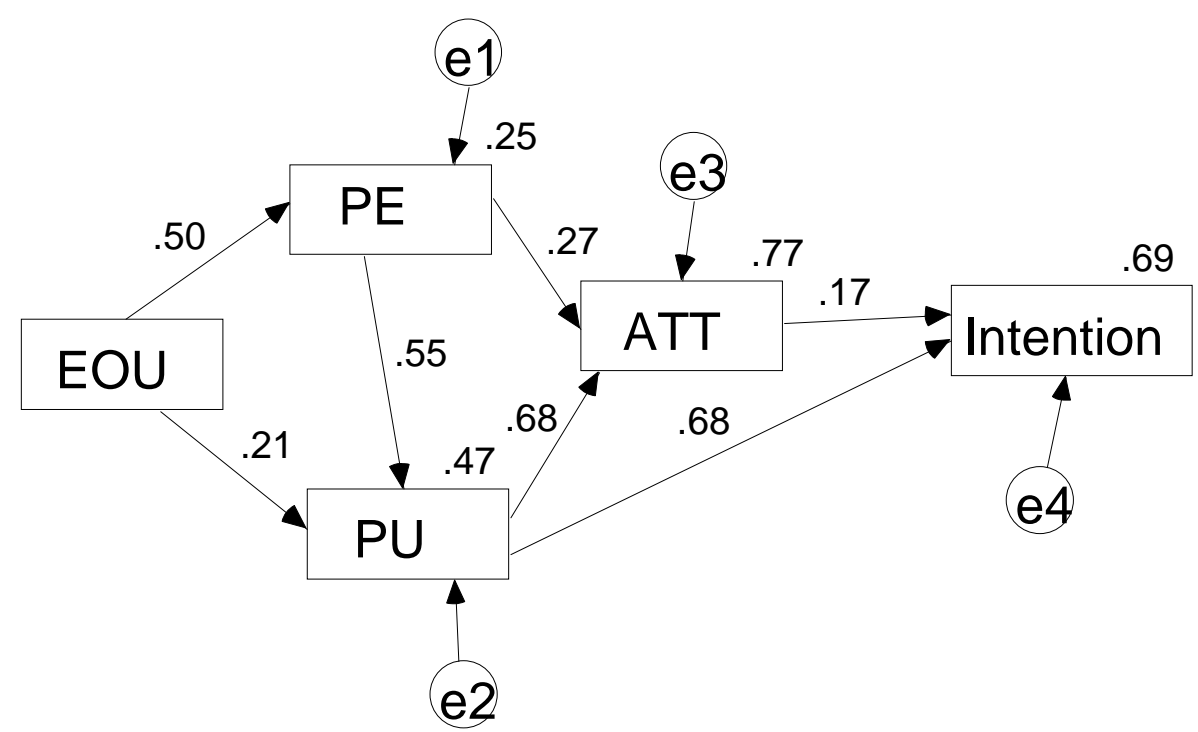

Figure 2: Structural Model With Inter-Construct Correlations

Results indicate most of the relationships in the proposed model are statistically significant and in the predicted directions. Five hypotheses are supported at $\mathrm{p}<0.01$ and one supported at $\mathrm{p}<0.05$. Table 2 summarizes the results of hypothesis testing.

Table 2: Results Of Hypothesis Testing

\begin{tabular}{|l|l|l|l|}
\hline Hypotheses & Symbols & Std. Coefficients & p \\
\hline H1. PEOU is positively associated with PU. & PEOU $\rightarrow$ PU & .211 & $<.05$ \\
\hline H2: PU is positively associated with ATT. & PU $\rightarrow$ ATT & .675 & $<.01$ \\
\hline H3: PU is positively associated with Intention. & PU $\rightarrow$ Intention & .678 & $<.01$ \\
\hline H4: ATT is positively associated with Intention. & ATT $\rightarrow$ Intention & .174 & $>.05$ (n.s.) \\
\hline H5. PE is positively associated with PU. & PE $\rightarrow$ PU & .554 & $<.01$ \\
\hline H6: PEOU is positively associated with PE. & PEOU $\rightarrow$ PE & .499 & $<.01$ \\
\hline H7: PE is positively associated with ATT. & PE $\rightarrow$ ATT & .268 & $<.01$ \\
\hline
\end{tabular}

\section{CONCLUSION}

Findings of this study provide evidence that exTAM is an applicable model in examining factors influencing learners' attitudes and behavioural intentions in relation to the use of an interactive learning technology, such as clickers in the classroom. Instead of examining observable performance differences, this study explores the affective dimension of student learning outcomes through understanding students' psychological learning processes. This study complements existing research by answering how cognitive factors influence students' perceptions and attitudes toward using educational technology. As Clark (1994) points out, any effect of using instructional media does not come from the use of media itself, but is determined by how the media are utilized. We hope that the findings of this study will help researchers and educators better develop and employ learning technologies in a way that is perceived most favourably by learners and that fulfills the instructional goals most effectively.

\section{AUTHOR INFORMATION}

Xiaoyu Wu is an assistant professor of Economics at Ramapo College of New Jersey. She has a Ph.D. in Economics from the University of California, Riverside. Her research interests include productivity analysis, applied 
econometrics, environmental economics, and educational technology. Her research has appeared in Economics Bulletin, Journal of Applied Business Research, American Journal of Business Education, and numerous conference proceedings.

Yuan Gao is an associate professor of Information Systems at Ramapo College of New Jersey. He has an MBA and a Ph.D. in Business from Baruch College-CUNY. His research interests include human computer interaction, web interface design, e-commerce, and educational technology. His research has appeared in The DATA BASE for Advances in Information Systems, The Electronic Library, Journal of Electronic Commerce in Organizations, Journal of Applied Business Research, American Journal of Business Education, Review of Business Information Systems, and Journal of Educational Multimedia and Hypermedia.

\section{REFRENCES}

1. Ajzen, I., \& Fishbein, M. (1980). Understanding Attitudes and Predicting Social Behavior. Englewood Cliffs, NJ: Prentice-Hall.

2. Alavi, M., \& Leidner, D.E. (2001). Research commentary: technology mediated learning - a call for greater depth and breadth of research. Information Systems Research, 12(1), 1-10.

3. Batra, R., \& Ray, M.L. (1986). Affective responses mediating acceptance of advertising. Journal of Consumer Research, 13, 234-249.

4. Bekele, T.A., \& Menchaca, M.P. (2008). Research on Internet supported learning: a review. The Quarterly Review of Distance Education, 9(4), 373-405.

5. Benbunan-Fish, R., \& Hiltz, S.R. (2003). Mediators of the effectiveness of online courses. IEEE Transactions on Professional Communication, 46(4), 298-312.

6. Bruner, G.C., \& Kumar, A. (2005). Explaining consumer acceptance of handheld Internet devices. Journal of Business Research, 58(5), 553-558.

7. Cain, J., \& Robinson, E. (2008). A Primer on audience response system: current applications and future considerations. American Journal of Pharmaceutical Education, 72(4), 1-6.

8. Clark, R.R. (1994). Media will never influence learning. Educational Technology Research and Development, 42(2), 21-29.

9. Davis, F.D., Bagozzi, R.P., \& Warshaw, P.R. (1989). User acceptance of computer technology: comparison of two theoretical models. Management Science, 35(8), 982-1003.

10. Davis, F.D., Bagozzi, R.P., \& Warshaw, P.R. (1992). Extrinsic and Intrinsic Motivation to Use Computers in the Workplace. Journal of Applied Social Psychology, 22(14), 1111-1132.

11. Ducoffe, R.H. (1996). Advertising value and advertising on the Web. Journal of Advertising Research, 36(5), 21-34.

12. Gao, Y., Koufaris, M., \& Ducoffe, R. (2004). An experimental study of the effects of promotional techniques in web-based commerce. Journal of Electronic Commerce in Organizations, 2(3), 1-21.

13. Gefen, D., Karahanna, E., \& Straub, D.W. (2003). Trust and TAM in online shopping: an integrated model. MIS Quarterly, 27(1), 51-90.

14. Hrastinski, S., \& Keller, C. (2007). Computer-mediated communication in education: a review of recent research. Educational Media International, 44(1), 61-77.

15. Hu, L.T., \& Bentler, P.M. (1999). Cutoff criteria for fit indexes in covariance structure analysis: conventional criteria versus new alternatives. Structural Equation Modeling, 6(1), 1-55.

16. Koufaris, M. (2002). Applying the technology acceptance model and flow theory to online consumer behavior. Information Systems Research, 13(2), 205-223.

17. Lu, Y., Zhou, T., \& Wang, B. (2008). Exploring Chinese users' acceptance of instant messaging using the theory of planned behavior, the technology acceptance model, and the flow theory. Computers in Human Behavior, 6(2), 1-11.

18. Mathieson, K. (1991). Predicting user intentions: comparing the technology acceptance model with the theory of planned behavior. Information Systems Research, 2(3), 173-191.

19. McQuail, D. (1983). Mass Communication Theory: An Introduction. London: Sage Publications.

20. Mitchell, A.A., \& Olson, J.C. (1981). Are product attribute beliefs the only mediator of advertising effects on brand attitudes? Journal of Marketing Research, 18(3), 318-332. 
21. Moon, J., \& Kim, Y. (2001). Extending the TAM for a World-Wide-Web context. Information \& Management, 38(4), 217-230.

22. Novak, T. P., Hoffman, D. L., \& Yung, Y.F. (2000). Measuring the customer experience in online environments: A structural modeling approach. Marketing Science, 19(Winter), 22-42.

23. Nunnally, J.C. (1978). Psychometric Theory. New York: McGraw Hill.

24. Shen, J., \& Eder, L.B. (2009). Exploring intentions to use virtual worlds for business. Journal of Electronic Commerce Research, 10(2), 94-103.

25. Sprague, E.W., \& Dahl, D.W. (2010). Learning to click: an evaluation of the personal response system clicker technology in introductory marketing courses. Journal of Marketing Education, 32(1), 93-104.

26. Stafford, T.F. (2005). Understanding motivations for Internet use in distance education. IEEE Transactions on Education, 48(2), 301-306.

27. Stowell, J. R., \& Nelson, J. M. (2007). Benefits of electronic audience response systems on student participation, learning, and emotion. Teaching of Psychology, 34(4), 253-258.

28. Szajna, B. (1996). Empirical evaluation of the revised technology acceptance model. Management Science, 42(1), 85-92.

29. Wan, Z., Fang, Y., \& Neufeld, D.J. (2007). The role of information technology in technology-mediated learning: a review of the past for the future. Journal of Information Systems Education, 18(2), 183-192.

30. Wood, W.B. (2004) Clickers: a teaching gimmick that works. Developmental Cell, 7(6), 796-798. 


\section{APPENDIX}

\section{Survey Items}

(Items are mixed and separated on the survey.)

Instructions: Circle the number that best indicates your agreement or disagreement with each statement, from 1 being strongly disagree to 7 being strongly agree.

Perceived Ease of Use (PEOU):

Learning to use iclicker would be easy for me.

My interaction with iclicker was clear and understandable.

It would be easy for me to use iclicker.

I found iclicker easy to use.

\section{Perceived Usefulness (PU):}

Using iclicker would enhance my effectiveness in learning.

Using iclicker would improve my course performance.

Using iclicker would increase my productivity in my course work.

I found using iclicker useful.

\section{Perceived Enjoyment (PE):}

Using iclicker is enjoyable.

Using iclicker is entertaining.

Using iclicker is fun.

\section{Attitude (ATT):}

I believe it is a good idea to use iclicker in my future courses.

I have a generally favorable attitude toward using iclicker.

I dislike the idea of using iclicker (R).

\section{Intention:}

I intend to choose classes using iclicker if available.

I will recommend courses using iclicker to my friends.

I intend to take courses using iclicker in the future. 